\title{
Genetical

\section{Genetic variation in adiponectin, leptin and leptin receptors with reference to risk of breast cancer in Northeast obese women in India}

\author{
M. Khandouzi ${ }^{* *}$, M. Deka ${ }^{2}$ M. Narayan Baruah ${ }^{3}$, R. Rozati ${ }^{4}$, M.Kordafshari $^{5}$, \\ P. Kashyap ${ }^{6}$ and N. Kumari ${ }^{7}$ \\ 1,2,5,6,7 PhD Scholars, Department of Bioengineering and Technology, Gauhati University, Guwahati, Assam, \\ India.Ph: +918011588140, E-mail: majid.khandozi@gmail.com. \\ ${ }^{3}$ Department of Oncology in North East Cancer Hospital and Research Institute, Guwahati, Assam, India. \\ ${ }^{4}$ Department of Obstetrics \&t Gynecology in Owaisi Hospital \&t Research Centre, Hyderabad, A.P, India
}

\begin{abstract}
Adiponectin and leptin are adipose tissue derived hormones, adiponectin properties are anti-inflammatory, antiatherogenic, anti-diabetic, and plays an important role in the development and progression of various cancers, especially obesity-related cancers. Studies show the SNPs in adiponectin is cause of SNPs in insulin resistance, type2 diabetes and breast cancer. Leptin is an obesity mediator; leptin and its receptor are overexpressed in breast cancer, especially in high grade tumors. The aim of this study is to estimate the allele polymorphisms of adiponectin, leptin, leptin receptor in a population of northeast India and investigate the role of those polymorphisms that increase risk of breast cancer. The study type is a case-control. 205 patients with positive breast cancer as cases group and 205 people as controls group were determined genotyping by using PCR-RFLP. Comparing cases and controls, there is positive association between adiponectin SNPs $(276 \mathrm{G} / \mathrm{T}, 45 \mathrm{~T} / \mathrm{G})$ and leptin SNP and Breast cancer $(\mathrm{P}=0.04, \mathrm{OR}=1.64,95 \%$ $\mathrm{Cl}=1.00-2.62),(\mathrm{P}=0.05, \mathrm{OR}=1.77,95 \% \mathrm{CI}=0.96-3.17)$ \&t $(\mathrm{P}=0.04, \mathrm{OR}=1.44,95 \% \mathrm{Cl}=0.98-2.13)$. But there is no evidence for a strong association between leptin receptor SNPs $(109 \mathrm{~A} / \mathrm{G}, 223 \mathrm{~A} / \mathrm{G})$ and breast cancer $(\mathrm{P}=0.87$, $\mathrm{OR}=1.05,95 \% \mathrm{Cl}=0.43-2.91),(\mathrm{P}=0.31, \mathrm{OR}=0.56,95 \% \mathrm{Cl}=0.17-1.83)$. The results of this study indicate that the polymorphisms in the adiponectin and leptin may be a risk factor for breast cancer.
\end{abstract}

KEY WORDS: POLYMORPHISM, ADIPONECTIN, LEPTIN, LEPTIN RECEPTOR, OBESITY, BREAST CANCER

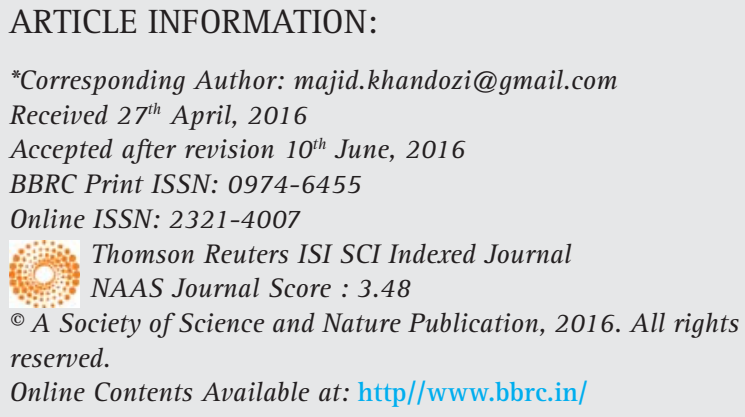




\section{INTRODUCTION}

Obesity is a risk factor for decreased survival in breast cancer patients (Reeves et al., 2007; Schapira et al., 1991). Adipocytokines are hormones produced by adipose tissue, and its circulating levels are correlated with obesity, they show an effect on cell proliferation, migration and invasion, they are found to be expressed in breast tissues (Fredriksson et al., 2006; Rose et al., 2004; Schaffler et al., 2007; Vona-Davis et al., 2007). Adiponectin has potent effects for insulin sensitizing, increases nitric oxide levels and decreases the rate of apoptosis and oxidative stress (Cheng et al., 2007; Kobayashi et al., 2004; Tschritter et al., 2003). In vitro studies, shows adiponectin is associated with growth inhibition and apoptosis induction in cancer cell lines (Byeon et al., 2010). In vivo studies in mice showed the developments of more intestinal tumors are associated with the disruptions in serum adiponectin (Mutoh et al., 2011). Many studies have also shown that the low levels of adiponectin are associated with increased body fat resulting in obesity (Maeda et al., 1996). Insulin is an important biomolecules, which plays an important role in the progression of metastatic breast cancer (Hollmann et al., 1997). In general, WHR (Waist to Hip Ratio) is one of the markers for insulin resistance and hyperinsulinemia, and an elevated ratio of WHR represents a higher abdominal fat distribution, which in turn is associated with both incidence and mortality of breast cancer (Borugian et al., 2003; Considine et al., 1996). Thus, both obesity and insulin involve in the development of breast cancer (Chen et al., 2006; Kang et al., 2007; Kelesidis et al., 2006; Korner et al., 2007; Mantzoros et al., 2004; Miyoshi et al., 2003; Maeda et al., 1996; Yang et al., 2009).

Leptin is the peptide hormone product of the obesity gene, it is mainly secreted from adipose tissue, and the secondary sources are placenta, stomach, and skeletal muscles (Zhang et al., 1994; Garaulet et al., 2000; Goodwin et al., 2005). It is involved in the regulation of body composition and weight, thus said to be as an important mediator of obesity (Schwartz et al., 1999). A single transmembrane protein, leptin receptor (superfamily of cytokines) exists in many tissues, and mediates the physiologic action of leptin. The interaction between leptin and leptin receptor plays an important role in angiogenesis, body weight homeostasis, hematopoiesis, immune processes and reproduction (Israel and Chua, 2010; Suzukawa, 2011).

Although, leptins have been inconclusive with breast cancer in some studies, both leptin and its receptors are shown to be over expressed in breast cancer, especially in high grade tumors (Han et al., 2008; Mantzoros et al., 1999; Petridou et al., 2000; Stattin et al., 2004; Ishikawa et al., 2004; Surmacz, 2007). The expression of leptin and its receptor is found in $70-80 \%$ of breast cancer cases (Bozcuk et al., 2004). In animal and human cell lines, leptin receptors are reported to be associated with increased tumor cell proliferation, and promotion of angiogenesis in benign and malignant epithelial breast cells, (Dieudonne, 2002; Hu, 2002; Li et al., 2004; Lim, 2005; Qian, 2011). The various SNPs (Single Nucleotide Polymorphisms) have been identified in the adiponectin, leptin and leptin receptor genes. The association studies between the SNPs in the adiponectin, leptin, leptin receptor and their possible association with breast cancer have shown little consistency (Cleveland et al., 2010; Kaklamani et al., 2008; Okobia et al., 2008; Snoussi et al., 2006; Teras et al., 2009; Woo et al., 2009).

Therefore, in order to study the association of SNPs in adiponectin and leptin receptors with respect to breast cancer, two SNPs in adiponectin gene (rs2241766 $(45 \mathrm{~T} / \mathrm{G})$ and rs1501299 $(276 \mathrm{G} / \mathrm{T}))$, one SNP in leptin gene (rs7799039 (2548G/A) and two in leptin receptor SNPs (rs $1137100(109 \mathrm{~A} / \mathrm{G})$ and rs $1137101(223 \mathrm{~A} / \mathrm{G})$ were taken in to consideration.

\section{MATERIAL AND METHODS}

\section{SAMPLE COLLECTION:}

In this study, $5 \mathrm{ml}$ blood samples were collected in EDTA vials from 205 northeast women patient with breast cancer diagnosed at the Northeast Cancer Hospital, Assam, India and 205 healthy Northeast women from Health Screening Center of Northeast Cancer Hospital, Assam, India between the period February 2013 to December 2014. All cases had never received surgery, chemotherapy or radiation therapy, and the study has been approved by Gauhati University ethical committee (GUEC-04/2015) and the written informed consent to participate (i.e., case and controls) in the study was obtained from all subjects.

\section{DNA ISOLATION AND PCR-RFLP}

Phenol-chloroform method was used to isolate genomic DNA (Deoxyribonucleic acid) from the collected blood, and the quantity of DNA was determined by spectrophotometer. Amplification of the gene polymorphism regions was carried out by PCR (Polymerase Chain Reaction) and the RFLP (Restriction Fragment Length Polymorphism) was used to identify the Single nucleotide polymorphism regions of adiponectin (45T/G and 276G/T), leptin (2548G/A), and leptin receptor (109A/G and 223A/G). The PCR primer sequences (Invitrogen, India) used for adiponectin SNPs (45T/G and 276G/T); leptin SNP (2548G/A), and leptin receptor SNPs (109A/G 


\begin{tabular}{|c|c|c|}
\hline Percent \% & Case No \% & Control No \% \\
\hline Age (years) means \pm sd & $47.59 \pm 18.73$ & $45.07 \pm 17.55$ \\
\hline BMI (Body Mass Index) (Kg/m2) & $27.9 \pm 6$ & $26.0 \pm 3$ \\
\hline \multicolumn{3}{|l|}{ Age of Diagnosis } \\
\hline $21-40$ & $54(26.7 \%)$ & $82(40 \%)$ \\
\hline $41-60$ & $123(60 \%)$ & $100(48.9 \%)$ \\
\hline Above 61 & $28(13.3 \%)$ & $23(11.1 \%)$ \\
\hline Smoking women & $36(17.8 \%)$ & $32(15.6 \%)$ \\
\hline women with previous smoking & $9(4.4 \%)$ & $18(8.9 \%)$ \\
\hline Non smoking women & $160(77.8 \%)$ & $155(75.5 \%)$ \\
\hline Waist Circumference(WC) (cm) & $102 \pm 15$ & $102.5 \pm 9$ \\
\hline Systolic blood pressure (mmHg) & $131 \pm 20$ & $130 \pm 12$ \\
\hline Diastolic blood pressure (mmHg) & $80.6 \pm 6$ & $81 \pm 8$ \\
\hline Total Cholesterol $(\mathrm{mmol} / \mathrm{L})$ & $6 \pm 1$ & $6.6 \pm 1.1$ \\
\hline HDL (mmol/L) & $1.2 \pm 0.5$ & $1.2 \pm 0.07$ \\
\hline LDL (mmol/L) & $3.9 \pm 2$ & $4.4 \pm 0.6$ \\
\hline White women & $37(18 \%)$ & $42(20.5 \%)$ \\
\hline Black women & $98(47.8 \%)$ & $86(42 \%)$ \\
\hline Other & $70(34.2 \%)$ & 77 (37.5\%) \\
\hline Drinking women & $53(25.85 \%)$ & $23(11.2 \%)$ \\
\hline Women with previous drinking & $24(11.7 \%)$ & $15(7.3 \%)$ \\
\hline Non drinking women & 128 (62.45\%) & 167 (81.5\%) \\
\hline
\end{tabular}

and 223A/G) are shown in Table 2. PCR was standardized and carried out for about 34 cycles. The PCR products were separated on 1.5\% agarose gel, visualized with ethidium bromide. The different restriction enzymes (genome diagnostics private limited, India) used to study the respective gene polymorphisms by RFLP method was mentioned in Table 2.

The restriction enzyme digestion was carried out for $37^{\mathrm{C}}$ (overnight; 16 hours) for each gene separately, and the products were visualized on $2 \%$ agarose gel stained with ethidium bromide.

\section{STATISTICAL ANALYSIS}

The allele frequency differences between case and control groups were obtained using used $\mathrm{X}^{2}$ (Chi- square) test. For each SNP the OR (Odds Ratio) with CI (Confidence Interval) 95\% were calculated and the identification of

\begin{tabular}{|c|c|c|c|}
\hline Gene & Polymorphisms & PCR (F = Forward , R= Reverse) & $\begin{array}{l}\text { Restriction enzymes } \\
\text { used for RFLP }\end{array}$ \\
\hline \multirow[t]{4}{*}{ Adiponectin } & rs2241766 & F: 5'- GAAGTAGACTCTGCTGAGATGG - 3' & SmaI \\
\hline & & R:5'-TATCAGTGTAGGAGGTCTGTGATG-3' & \\
\hline & rs1501299 & F : 5’- ATGCAGCAAAGCCAAAGTCT - 3' & BsmI \\
\hline & & R : 5'- CCTGGTGAGAAGGGTGAGAA - 3' & \\
\hline \multirow[t]{2}{*}{ Leptin } & rs7799039 & F : 5'- TGTGTGTTCCCTGGTTCAAG - 3' & HhaI \\
\hline & & R : 5'- TTCCTGCAACATCTCAGCAC - 3' & \\
\hline \multirow[t]{4}{*}{ Leptin Receptor } & rs 1137100 & F : 5'- CACTGTTGCTTTCGGAGTGA - 3' & BsgI \\
\hline & & R:5'-TCATAGCCATAAGACATCTATTTCA- 3' & \\
\hline & rs 1137101 & F : 5'- CAGCCAAACTCAACGACACT -3' & BstEII \\
\hline & & R : 5'- GCCACTCTTAATACCCCCAGT - 3' & \\
\hline
\end{tabular}




\begin{tabular}{|c|c|c|c|c|c|}
\hline Genotype & Case $\%$ & Control \% & $95 \% \mathrm{CI}$ & OR & P-Value \\
\hline \multicolumn{6}{|c|}{ Adiponectin gene : rs2241766 (45T/G) } \\
\hline TT & $132(64.5 \%)$ & $146(71.2 \%)$ & $0.31-1.03$ & 0.56 & 0.05 \\
\hline TG & 64 (31.1 \%) & $50(24.4 \%)$ & $0.96-3.17$ & 1.77 & 0.05 \\
\hline GG & $9(4.4 \%)$ & $9(4.4 \%)$ & $0.16-9.02$ & 1.26 & 0.81 \\
\hline \multicolumn{6}{|l|}{ Allele } \\
\hline \multirow[t]{2}{*}{ T } & $328(80 \%)$ & 342 (83.4 \%) & & 1 & \\
\hline & & & $0.99-3.14$ & 1.75 & 0.05 \\
\hline G & $82(20 \%)$ & $68(16.6 \%)$ & & & \\
\hline \multicolumn{6}{|c|}{ Adiponectin gene : rs1501299 (276G/T) } \\
\hline GG & 110 (53.4 \%) & 141 (64.5 \%) & $0.36-0.92$ & 0.57 & 0.02 \\
\hline GT & $91(44.5 \%)$ & 59 (33.4 \%) & $1.00-2.62$ & 1.64 & 0.04 \\
\hline TT & $4(2.1 \%)$ & $5(2.1 \%)$ & $0.42-34.02$ & 3.75 & 0.23 \\
\hline \multicolumn{6}{|l|}{ Allele } \\
\hline G & $311(75.85 \%)$ & $341(83.1 \%)$ & & 1 & \\
\hline $\mathrm{T}$ & 99 (24.15\%) & 69 (16.9 \%) & $0.96-2.67$ & 1.67 & 0.04 \\
\hline
\end{tabular}

genotypes risk was performed using logistic regression analysis. Pearson $\mathrm{X}^{2}$ statistics with threshold of $\mathrm{P}<0.05$ for each SNP was used to test the Hardy-Weinberg equilibrium. SPSS (Statistical Package for Social Sciences) 16 software was used to perform the statistical analysis and the possibility less than 0.05 , was considered significant. Power and Sample Size Calculations was used to estimate the Power (http://biostat.mc.vanderbilt.edu/ wiki/Main/PowerSampleSize)..

\section{RESULTS}

Distribution of genotype frequencies of polymorphisms of adiponectin gene $(45 \mathrm{~T} / \mathrm{G}, 276 \mathrm{G} / \mathrm{T})$, leptin gene (2548G/A), and leptin receptor gene (109A/G, 223A/G) in breast cancer patients were in Hardy-Weinberg equilibrium (Table 3). Among these five polymorphisms tested, significant association with breast cancer was observed in adiponectin gene rs1501299 (276G/T) and leptin gene rs7799039 (2548G/A) polymorphisms among northeast women patients. However, it was noticed that the genotype frequencies of polymorphism of adiponectin gene $(276 \mathrm{G} / \mathrm{T})$ and leptin gene $(2548 \mathrm{G} / \mathrm{A})$ were found to be $\mathrm{P}=0.005$ and $\mathrm{P}=0.019$, and showed significantly different in the breast cancer patients and normal controls respectively. The frequency of the risk allele " $\mathrm{T}$ " in adiponectin gene $(276 \mathrm{G} / \mathrm{T})$ was significantly higher in patients with breast cancer (24.1\%) in comparison with the normal controls $(16.8 \%)$ and the allelic odds ratio was found to be 1.57 (95\% CI: 1.12-2.22, $\mathrm{P}=0.009$ ). The frequency of the risk allele "A" in leptin gene polymorphism $(2548 \mathrm{G} / \mathrm{A})$ was significantly higher in patients with breast cancer (42.0\%) in comparison with the normal controls (32.4\%) and the allelic odds ratio was found to be 1.51 (95\% CI: 1.13-2.00, $\mathrm{P}=0.005$ ).

The logistic regression analysis was performed to compare the frequencies of genotypes of cases and controls under an additive model, and the findings are presented in Table 3. Similar to the allelic association with breast cancer, the genotypes of the 276G/T (OR $=1.64,95 \% \mathrm{CI}: 1.00-2.62, \mathrm{P}=0.04)$ and $2548 \mathrm{G} / \mathrm{A}$ polymorphisms $(\mathrm{OR}=1.44,95 \% \mathrm{CI}: 0.98-2.13, \mathrm{P}=$ 0.04) showed a significant susceptibility to breast cancer respectively. However, the association with breast cancer was not observed in the other polymorphisms namely, adiponectin gene $(45 \mathrm{~T} / \mathrm{G})$ and leptin receptor gene $(109 \mathrm{~A} / \mathrm{G}, 223 \mathrm{~A} / \mathrm{G})$.

\section{DISCUSSION}

According to WHO (World Health organization), obesity is one of the $21^{\text {st }}$ greatest public challenges, and by 2015, it was estimated that more than 700 million adults will be obese. Obesity is found to be one of the major risk factor for breast cancer (Holmes and Willett, 2004); apart from this it is also associated with the increased risk for the number of cancers such as colon, prostate, liver. The cell signaling proteins or cytokines produced by adipose tissue are adipocytokines (i.e., adiponectin and leptin), which plays an important role in obesity 


\begin{tabular}{|c|c|c|c|c|c|}
\hline Genotype & Case $\%$ & Control \% & $95 \% \mathrm{CI}$ & OR & P-Value \\
\hline \multicolumn{6}{|c|}{ Leptin gene : rs7799039 (2548G/A) } \\
\hline GG & $69(33.3 \%)$ & $95(46.7 \%)$ & & 1 & \\
\hline GA & $100(48.9 \%)$ & $87(42.2 \%)$ & $0.98-2.13$ & 1.44 & 0.04 \\
\hline AA & $36(17.8 \%)$ & $23(11.1 \%)$ & $1.45-6.95$ & 3.15 & 0.001 \\
\hline \multicolumn{6}{|l|}{ Allele } \\
\hline G & $238(58.04 \%)$ & $277(67.5 \%)$ & & 1 & \\
\hline A & $172(41.96 \%)$ & $133(32.5 \%)$ & $1.17-2.05$ & 1.56 & 0.04 \\
\hline \multicolumn{6}{|c|}{ Leptin receptor : rs1137100 (109A/G) } \\
\hline AA & $9(4.4 \%)$ & $13(6.7 \%)$ & & 1 & \\
\hline AG & $59(28.9 \%)$ & $64(31.1 \%)$ & $0.43-2.91$ & 1.05 & 0.87 \\
\hline GG & $137(66.7 \%)$ & $128(62.2 \%)$ & $0.48-2.21$ & 1.02 & 0.95 \\
\hline \multicolumn{6}{|l|}{ Allele } \\
\hline A & $77(18.78 \%)$ & $90(21.95 \%)$ & & 1 & \\
\hline G & $333(81.22 \%)$ & $320(78.05 \%)$ & $0.39-2.94$ & 1.03 & 0.87 \\
\hline \multicolumn{6}{|c|}{ Leptin receptor : rs1137101 (223A/G) } \\
\hline AA & $5(2.2 \%)$ & $9(4.4 \%)$ & & 1 & \\
\hline AG & 54 (26.7 \%) & 37 (17.8 \%) & $0.17-1.83$ & 0.56 & 0.31 \\
\hline GG & $146(71.1 \%)$ & $159(77.8 \%)$ & $0.72-1.69$ & 1.1 & 0.66 \\
\hline \multicolumn{6}{|l|}{ Allele } \\
\hline A & $64(15.6 \%)$ & 55 (13.42 \%) & & 1 & \\
\hline G & 346 (84.4 \%) & $355(86.58 \%)$ & $0.85-1.3$ & 1.05 & 0.67 \\
\hline
\end{tabular}

related cancers, including breast cancer. These molecules are also known to be one of the causes for the association between obesity and breast cancer risks.

In the present study, we report that the genetic variation in adiponectin (45T/G and $276 \mathrm{G} / \mathrm{T})$ and leptin gene (2548G/A) showed significant association with breast cancer among northeast women patients. In this study we demonstrated that the genetic variation in the adiponectin and leptin may be genetic markers for breast cancer, and these genetic markers may be prognostic factors to predict breast cancer recurrence and death in northeast women population. According to the result of this study, polymorphisms in adiponectin (i.e., 45T/G and 276G/T) and leptin (i.e., 2548G/A) have shown increase risk for breast cancer.

In 2011, Al Khaldi et al. found that adiponectin gene $45 \mathrm{~T} / \mathrm{G}$ is associated with breast cancer, and also mentioned that the two polymorphisms (45T/G and 276G/T) of adiponectin gene might be the predisposing factors in various cancers in the Kuwait population (Al Khaldi et al., 2011). In the same year, Nyante et al. found that 45T/G and 276G/T polymorphisms were associated with breast cancer in whites and African Americans (Nyante et al., 2011). Apart, from breast cancer related studies, it is known that the adiponectin gene polymorphism $(45 \mathrm{~T} / \mathrm{G})$ showed a significant association for polycystic ovary syndrome risk (Ranjzad et al., 2012). Whereas, this polymorphism in type 2 diabetes did not show significant association in Yi and Han people of China (Wang et al., 2011).

In the present study, leptin gene polymorphism (2548G/A) shows significant association with breast cancer in northeast obese women in India. However, previous studies indicated the polymorphism in leptin did not show any association with breast cancer risk and also leptin serum levels showed no relationship with respect to breast cancer in old women (Mantzoros et al., 1999; Petridou et al., 2000).

In contrast, this polymorphism resulted in high leptin secretion and also associated with high risk of prostate cancer (Hoffstedt et al., 2002; Le Stunff et al., 2000; Kote-Jerai et al., 2003; Ribeiro et al., 2004). Although, this study did not measure serum leptin levels it is known that elevated serum leptin levels showed increased risk of developing breast cancer in comparison with normal levels (Han et al., 2005).

The present study did not show any significant association of leptin receptor polymorphism $(223 \mathrm{~A} / \mathrm{G}$ and 
$109 \mathrm{~A} / \mathrm{G}$ ), which is in agreement with the unexplanation of the association of this polymorphism in breast cancer (Woo et al., 2006). On the other hand, Quinton et al. indicated that leptin receptor SNPs 223A/G and 109A/G were associated with lower circulating leptin level (Quinton et al., 2001). Yiannakouris et al. have studied that carriers of the leptin receptor polymorphisms associated significantly with higher leptin level than persons with non carriers (Yiannakouris et al., 2001).

In previously, eight small breast cancer studies conducted in different countries evaluated seven candidate leptin receptor SNPs with inconsistent results. Han and Snoussi found a roughly fold statistically significant risk of breast cancer for 223A/G (Han et al., 2008; Snoussi et al., 2006). In others study, Woo and Gallicchio found no association between leptin receptor SNPs $(223 \mathrm{~A} / \mathrm{G}$, 109A/G) and breast cancer (Woo et al., 2006; Gallicchio et al., 2007). Liu, et al.reported a suggestion of an association between 109A/G polymorphism and breast tumor size but among premenopausal women only (Liu et al., 2007). In addition, Petridou et al. have found no relationship between leptin serum levels and breast cancer in old women (Petridou et al., 2000). A recent study has demonstrated that subjects with elevated serum leptin levels displayed increased risk of developing breast cancer than those with the normal levels (Han et al., 2005). Thus, association between hormone levels and the respective gene polymorphism would give better insight into the etiology of the breast cancer risk and may help to identify the women who are at risk.

\section{CONCLUSION}

In this study we investigated the association of two adiponectin gene SNPs (45T/G and 276G/T), leptin gene SNP (2548G/A), and two leptin receptor SNPs (109A/G, $223 \mathrm{~A} / \mathrm{G}$ ) and their possible association with breast cancer in a Northeast women population. Our results indicates polymorphisms in adiponectin gene (276G/T) and leptin gene (2548G/A) have shown increased risk of breast cancer, and might be the genetic markers for breast cancer. The addition of remaining SNPs in adiponectin, leptin, leptin receptor genes along with hormonal level measurement could be useful as genetic markers for breast cancer. To our knowledge, our study provides information on the adiponectin SNPs (45T/G, 276G/T), leptin SNP2548G/A, leptin receptor SNPs $(109 \mathrm{~A} / \mathrm{G}, 223 \mathrm{~A} / \mathrm{G})$ and the risk of breast cancer in Northeast women population.

\section{ACKNOWLEDGEMENTS}

This project is supported by Bioengineering and Technology Department of Gauhati University. The authors like to say thanks to all of the participants who kindly participated in this study.

\section{REFERENCES}

Al Khaldi RM, Al Mulla F, Al Awadhi S, Kapila K, Mojiminiyi OA (2011). Associations of single nucleotide polymorphisms in the adiponectin gene with adiponectin levels and cardiometabolic risk factors in patients with cancer. Dis Markers, 30: 197-212.

Borugian MJ, Sheps SB, Kim-Sing C (2003). Waist to hip ratio and breast cancer mortality. Am J Epidemiol, 158:963-8.

Bozcuk H, Uslu G, Samur M (2004). Tumour necrosis factoralpha, interleukin-6, and fasting serum insulin correlate with clinical outcome in metastatic breast cancer patients treated with chemotherapy. Cytokine, 27:58-65.

Byeon JS, Jeong JY, Kim MJ, Lee SM, Nam WH, Myung SJ (2010). Adiponectin and adiponectin receptor in relation to colorectal cancer progression. Int J Cancer, 127: 2758-67.

Chen DC, Chung YF, Yeh YT, Chaung HC, Kuo FC, Fu OY, Chen HY, Hou MF, Yuan SS (2006). Serum adiponectin and leptin levels in Taiwanese breast cancer patients. Cancer Lett, 237:109-114.

Cheng KK, Lam KS, Wang Y, Huang Y, Carling D, Wu D (2007). Adiponectininduced eNOS activation and nitric oxide production are mediated by APPL1 in endothelial cells. Diabetes, 56:1387-94.

Cleveland RJ, Gammon MD, Long CM, Gaudet MM, Eng SM, Teitelbaum SL, Neugut AI, Santella RM (2010). Common genetic variations in the lep and lepr genes, obesity and breast cancer incidence and survival. Breast Cancer Res Treat, 120:745-752.

Considine RV, Sinha MK, Heiman ML (1996). Serum immunoreactive-leptin concentrations in normal-weight and obese humans. N Engl J Med, 334:292-5.

Dieudonne MN (2002). Leptin mediates a proliferative response in human MCF7 breast cancer cells. Biochem Biophys Res Commun, 293: 622-628.

Fredriksson J, Carlsson E, Orho-Melander M, Groop L, Ridderstrale M (2006). A polymorphism in the adiponectin gene influences adiponectin expression levels in visceral fat in obese subjects. Int J Obes, 30:226-232.

Gallicchio L, McSorley MA, Newschaffer CJ, Huang HY, Thuita LW, Hoffman SC (2007). Body mass, polymorphisms in obesityrelated genes, and the risk of developing breast cancer among women with benign breast disease. Cancer Detect Prev, 31:95101.

Garaulet M, Pe'rex-Llamas F, Fuente T (2000). Anthropometric, computed tomography and fat cell data in an obese population: relationship with insulin, leptin, tumor necrosis factoralpha, sex hormone-binding globulin and sex hormones. Eur J Endocrinol, 143:657-66.

Goodwin PJ, Ennis M, Fantus IG (2005). Is leptin a mediator of adverse prognostic effects of obesity in breast cancer? J Clin Oncol, 23:6037-42. 
Han C, Zhang HT, Du L, Liu X, Jing J, Zhao X, Tian B (2005). Serum levels of leptin, insulin, and lipids in relation to breast cancer in china. Endocrine, 26:19-24.

Han C, Zhang HT, Du L, Liu X, Jing J, Zhao X, Tian B (2005). Serum levels of leptin, insulin, and lipids in relation to breast cancer in china. Endocrine, 26:19-24.

Han CZ, Du LL, Jing JX, Zhao XW, Tian FG, Shi J (2008). Associations among Lipids, Leptin, and Leptin Receptor Gene Gin223Arg Polymorphisms and Breast Cancer in China. Biol Trace Elem Res.

Han CZ, Du LL, Jing JX, Zhao XW, Tian FG, Shi J, Tian BG, Liu XY, Zhang LJ (2008). Associations among lipids, leptin, and leptin receptor gene gin223arg polymorphisms and breast cancer in china. Biol Trace Elem Res, 126:38-48.

Hoffstedt J, Eriksson P, Mottagui-Tabar S, Arner P (2002). A polymorphism in the leptin promoter region (-2548 G/A) influences gene expression and adipose tissue secretion of leptin. Horm Metab Res, 34:355-359.

Hollmann M, Runnebaum B, Gerhard I (1997). Impact of waisthip-ratio and body-mass-index on hormonal and metabolic parameters in young, obese women. Int $\mathrm{J}$ Obes Relat Metab Disord, 21: 476-83.

Holmes MD, Willett WC (2004). Does diet affect breast cancer risk? Breast Cancer Res, 6: 170-178.

$\mathrm{Hu} \mathrm{X}$ (2002). Leptin-a growth factor in normal and malignant breast cells and for normal mammary gland development. J Natl Cancer Inst, 94:1704-1711.

Ishikawa M, Kitayama J, Nagawa H (2004). Enhanced expression of leptin and leptin receptor (OB-R) in human breast cancer. Clin Cancer Res, 10:4325-4331.

Israel D, Chua S Jr (2010). Leptin receptor modulation of adiposity and fertility. Trends Endocrinol Metab, 21:10-16.

Kaklamani VG, Sadim M, Hsi A, Offit K, Oddoux C, Ostrer H, Ahsan H, Pasche B, Mantzoros C (2008). Variants of the adiponectin and adiponectin receptor 1 genes and breast cancer risk. Cancer Res, 68:3178-3184.

Kang JH, Yu BY, Youn DS (2007). Relationship of serum adiponectin and resistin levels with breast cancer risk. J Korean Med Sci, 22:117-121.

Kelesidis I, Kelesidis T, Mantzoros CS (2006). Adiponectin and cancer: a systematic review. Br J Cancer, 94:12211225.

Kobayashi H, Ouchi N, Kihara S, Walsh K, Kumada M, Abe Y (2004). Selective suppression of endothelial cell apoptosis by the high molecular weight form of adiponectin. Circ Res, 94:e27-31.

Korner A, Pazaitou-Panayiotou K, Kelesidis T, Kelesidis I, Williams CJ, Kaprara A, Bullen J,Neuwirth A, Tseleni S, Mitsiades N, Kiess W, Mantzoros CS (2007). Total and high-molecularweight adiponectin in breast cancer: in vitro and in vivo studies. J Clin Endocrinol Metab, 92: 1041-1048.

Kote-Jerai Z, Singh R, Durocher F, Easton D, Edwards SM, Ardern-Jones A, Dearnaley DP, Houlston R, Kirby R, Eeles R
(2003). Association between leptin receptor gene polymorphisms and early-onset prostate cancer. BJU Int, 92:109-112.

Le Stunff C, Le Bihan C, Schrk NJ, Bougneres P (2000). A common Promoter Variant of the Leptin Gene Is Associated With changes in the Relationship between Serum Leptin and Fat Mass in Obese Girls. Diabetes, 49:2196-2200.

Li WY, Lai BT, Zhan XP (2004). The relationship between genetic polymorphism of metabolizing enzymes and the genetic susceptibility to lung cancer. Zhonghua Liu Xing Bing Xue Za Zhi, 25:1042-1045.

Lim YJ (2005). Epidermal growth factor gene polymorphism is different between schizophrenia and lung cancer patients in Korean population. Neurosci Lett, 374:157-160.

Liu CL, Chang YC, Cheng SP, Chern SR, Yang TL, Lee JJ (2007). The roles of serum leptin concentration and polymorphism in leptin receptor gene at codon 109 in breast cancer. Oncology, 72:75-81.

Maeda K, Okubo K, Shimomura I, Funahashi T, Matsuzawa Y, Matsubara K (1996). CDNA cloning and expression of a novel adipose specific collagen-like factor, apM1 (adipose most abundant gene transcript 1). Biochem Biophys Res Commun, 221:286-9.

Maeda K, Okubo K, Shimomura I, Funahashi T, Matsuzawa Y, Matsubara K (1996). CDNA cloning and expression of a novel adipose specific collagen-like factor, apM1 (adipose most abundant gene transcript 1). Biochem Biophys Res Commun, 221:286-9.

Mantzoros C S, Bolhke K, Moschos S, Cramer C S (1999). Leptin in relation to carcinoma in situ of the breast: a study of premenopausal cases and controls. Int J Cancer, 80:523-526.

Mantzoros C, Petridou E, Dessypris N, Chavelas C, Dalamaga M, Alexe DM, Papadiamantis Y, Markopoulos C, Spanos E, Chrousos G, Trichopoulos D (2004). Adiponectin and breast cancer risk. JClin Endocrinol Metab, 89:1102-1107.

Miyoshi Y, Funahashi T, Kihara S, Taguchi T, Tamaki Y, Matsuzawa Y, Noguchi S (2003). Association of serum adiponectin levels with breast cancer risk. Clin Cancer Res, 9:5699-5704.

Mutoh M, Teraoka N, Takasu S, Takahashi M, Onuma K, Yamamoto M (2011). Loss of adiponectin promotes intestinal carcinogenesis in min and wild-type mice. Gastroenterology, 40: $2000-8$.

Nyante SJ, Gammon MD, Kaufman JS, Bensen JT, Lin DY (2011). Common genetic variation in adipone-ctin, leptin, and leptin receptor and association with breast cancer subtypes. Breast Cancer Res Treat, 129: 593-606.

Okobia MN, Bunker CH, Garte SJ, Zmuda JM, Ezeome ER, Anyanwu SN, Uche EE, Kuller LH, Ferrell RE, Taioli E (2008). Leptin receptor gln223arg polymorphism and breast cancer risk in Nigerian women: a case control study. BMC Cancer, 8:338.

Petridou E, Papadiamantis Y, Markopoulos C , Spanos E, Dessypris N, Trichopoulos D (2000). Leptin and insulin growth factor I in relation to breast cancer (Greece). Cancer Causes Control, 11:383-388. 
Petridou E, Papadiamantis Y, Markopoulos C , Spanos E, Dessypris N, Trichopoulos D (2000). Leptin and insulin growth factor I in relation to breast cancer (Greece). Cancer Causes Control, 11:383-388.

Qian Q (2011). Meta analysis of association between Ser326Cys polymorphism of hOGG1 gene and risk of lung cancer. Zhongguo Fei Ai Za Zhi, 14:205-210.

Quinton ND, Alisson JL, Ross RJM, Eastell R, Blakemore AIF (2001). A single nucleotide polymorphism (SNP) in the leptin receptor is associated with BMI, fat mass and leptin levels in postmenopausal Caucasian woman. Human Genet, 108:233236.

Ranjzad F, Mahmoudi T, Irani Shemirani A, Mahban A, Nikzamir A (2012). A common variant in the adiponectin gene and polycystic ovary syndrome risk. Mol Biol Rep, 39: 23132319.

Reeves GK, Pirie K, Beral V (2007). Cancer incidence and mortality in relation to body mass index in the million women study: cohort study. BMJ, 335:1134-39.

Ribeiro R, Vasconcelos A, C osta S, Pinto D, Morais A, Oliveira J, Lobo F, Lopes C , Medeiros R (2004). Overexpressing Leptin Genetic Polymorphism (-2548 G/A) Is Associated With Susceptibility to Prostate cancer and Risk of Advanced Disease. Prostate, 59: 268-274.

Rose DP, Komninou D, Stephenson GD (2004). Obesity, adipocytokines, and insulin resistance in breast cancer. Obes Rev, 5:153-165.

Schaffler A, Scholmerich J, Buechler C (2007). Mechanisms of disease: adipokines and breast cancerendocrine and paracrine mechanisms that connect adiposity and breast cancer. Nat Clin Pract Endocrinol Metab, 3:345-354.

Schapira DV, Kumar NB, Lyman GH, Cox CE (1991). Obesity and body fat distribution and breast cancer prognosis. Cancer, 67: 523-8.

Schwartz MW, Baskin DG, Kaiyala KJ, Woods SC (1999). Model for the regulation of energy balance and adiposity by the central nervous system 1-3. Am J Clin Nutre, 69:58496.

Snoussi K, Strosberg AD, Bouaouina N, Ben Ahmed S, Helal AN, Chouchane L (2006). Leptin and leptin receptor polymorphisms are associated with increased risk and poor prognosis of breast carcinoma. BMC Cancer, 6:38.

Snoussi K, Strosberg AD, Bouaouina N, Ben Ahmed S, Helal AN, Chouchane L (2006). Leptin and leptin receptor polymor- phisms are associated with increased risk and poor prognosis of breast carcinoma. BMC Cancer, 6: 38.

Stattin P, Soderberg S, Biessy C, Lenner P, Hallmans G, Kaaks $\mathrm{R}$, Olsson T (2004). Plasma leptin and breast cancer risk: a prospective study in northern Sweden. Breast Cancer Res Treat, 86:191-196.

Surmacz E (2007). Obesity hormone leptin: a new target in breast cancer? Breast Cancer Res, 9:301.

Suzukawa M (2011). Leptin enhances survival and induces migration, degranulation, and cytokine synthesis of human basophils. J Immunol, 186:5254-5260.

Teras LR, Goodman M, Patel AV, Bouzyk M, Tang W, Diver WR, Feigelson HS (2009). No association between polymorphisms in lep, lepr, adipoq, adipor1, or adipor2 and postmenopausal breast cancer risk. Cancer Epidemiol Biomarkers Prev, 18: 2553-2557.

Tschritter 0, Fritsche A, Thamer C, Haap M, Shirkavand F, Rahe S (2003). Plasma adiponectin concentrations predict insulin sensitivity of both glucose and lipid metabolism. Diabetes, 52:239-43.

Vona-Davis L, Howard-McNatt M, Rose DP (2007). Adiposity, type 2 diabetes and the metabolic syndrome in breast cancer. Obes Rev, 8:395-408.

Wang B, Wang C, Wei D, Zhang J, He H (2011). An association study of SNP $+45 \mathrm{~T}>\mathrm{G}$ of the AdipoQ gene with type 2 diabetes in Yi and Han people in China. Int J Vitam Nutr Res, 81: 392-397.

Woo HY, Park H, Ki CS, Park YL, Bae WG (2006). Relationships among serum leptin, leptin receptor gene polymorphisms, and breast cancer in Korea. Cancer Lett, 237:137-142.

Woo HY, Park H, Ki CS, Park YL, Bae WG (2006). Relationships among serum leptin, leptin receptor gene polymorphisms, and breast cancer in Korea. Cancer Lett, 237: 137-42.

Yang P, Zhou Y, Chen B, Wan HW, Jia GQ, Bai HL (2009). Overweight, obesity and gastric cancer risk: results from a metaanalysis of cohort studies. Eur J Cancer, 45: 2867-73.

Yiannakouris N, Yannakoulia M, Melistas L, C han JL, KlimisZacas D, Mantrozos C S (2001). The Q223R polymorphism of the leptin receptor gene is significantly associated with obesity and predicts a small percentage of body weight and body composition variability. J Clin Endocrinol Metab, 86: 4434-4439.

Zhang Y, Proenca R, Maffei M, Barone M, Leopold L, Friedman JM (1994). Positional cloning of the mouse obese gene and its human homologue. Nature, 372:425-32. 